\title{
Optimization of Urban Passenger Transport Route Network Parameters in Conditions of Structural Transformations of City Social and Economical Development
}

\author{
Vladimir Belokurov ${ }^{1 *}$, Murat Bedanokov ${ }^{2}$, Yusuf Guketlev ${ }^{2}$, Yana Tkacheva ${ }^{2}$, and Eljdar \\ Guketlev $^{1}$ \\ ${ }^{1}$ Voronezh State University of Forestry and technologies named after G.F. Morozov, 8 Timiryazev \\ str., Voronezh, 394087, Russia \\ ${ }^{2}$ Maikop State Technological University, 191 Pervomajskaya str., Maikop, 385000, Russia
}

\begin{abstract}
This article presents the materials related to the optimization of the route network parameters of passenger transport on the example of the city of Maykop. The scheme of the main directions of the route network and the analysis of the urban transport network of the city of Maykop. Recommendations for optimizing the parameters of the route network of passenger transport in Maykop.
\end{abstract}

\section{Introduction}

Transport networks mostly depends on the city planning. They are planned according to the existing street plans. Old cities transport network has serious cons that will require radical measures to be solved. New cities transport network is designed taking into account passengers minimum time spend, with additional capacity and with city growing prospect.

\section{Theory}

Transport network is based on the following basic principles: all the city districts are connected by straight routes with the most possible short distance; the routes are lined on to the main passenger flow and their length is determined according to the total city area and the number of rolling stock units on the route; transport network must provide expected mobile units capacity.

The city passenger transport routes can be of two types: general - with all the stops, speed - express and semiexpress - with limited stops. There are shortened routes, copying the main route part during a whole day or some daytime [3,7-9,11-13].

The main demands to the route network are the total coherence with passenger flow characteristics, that must be carefully studied both during projecting and using route network. At the project stage, they are determined by futuristic calculations based on theoretical

* Corresponding author opbd_vglta@mail.ru 
forecasting. When operating route networks, passenger traffic is studied by field survey methods and questioning [5-7].

Nowadays Maykop is the capital of the Republic of Adygeya. With 144 thousand citizens. Maikop is divided into lots of districts. The most popular are Cheremushky, Mayak, Center and Nefterazvedka. These districts have most developed infrastructure and well spread out net of urban transport routes. There are a lot of schools, shops and kindergartens, as well as universities. And districts Church, Kuzhorsky, Shovgenovsky gorodok, Stariy bazar, Konditerskaya fabrica, Voskhod and Mikhaylovo. Nowadays the following directions of Maykop social and economical development can be identified: the urban agglomeration is gradually transformed from the republic center, with the predominance of products in the city economics structure with a clear predominance in the structure of the tertiary sector economics branches (transport, education, business service etc.).

Service sector, public catering and retail trade are developing. New modern objects of culture and sport complexes are built in Maykop.

At the same time, outside the city, the construction of second-order centers is developing, which is usually formed along the highways connecting the city center with residential areas: trade zones, industrial and household service complexes, entertainment enterprises, hotel and restaurant services, etc.

It is worth paying attention to the transfer of residential areas, wholesale enterprises outside the city center, and formation of transport and logistic centers. Organization of passenger transportation in Maykop is carried out be municipal transport and commercial carriers. The organizational structure of municipal transport is represented by one trolleybus management. The structure of urban passenger transport of Maykop is presented in table 1 .

Table 1. Maykop Urban Passenger Transport Structure.

\begin{tabular}{|c|c|}
\hline \multicolumn{2}{|c|}{ City Passenger Transport } \\
\hline Municipal Transport & Commercial Transport \\
\hline 1. Maikop Trolleybus Management (MTM) & $\begin{array}{c}\text { 1. Passenger transportation by buses of average capacity } \\
\text { 2. Passenger transportation by buses of low capacity } \\
\text { (route taxi) }\end{array}$ \\
& 3. Passenger transportation by cars \\
& \\
\hline
\end{tabular}

The network of passenger routes is controlled by the department of Maykop urban infrastructure.

Transportation on municipal routes are organized based on municipal contract at social tariffs and using budget money to finance the carrier.

The total number of rolling stock in passenger transport urban structure is 345 , including trolleybuses -35 units, commercial buses -310 units.

Private carriers emerging on the urban transport network was one of the main reasons for the deterioration of municipal enterprises financial condition and the industry as a whole. This is associated with the emergening of a "route corridor", i.e. on a long distance, simultaneously operate different ownership forms enterprises, transport of different capacities and with different tariffs.

Of course, urban transport and private carriers perform equal functions, but they work in unequal economic conditions.

The number of commercial buses is 310 units nowadays. In comparison with year 2016 commercial buses transported 9.9 million people. The number of buses significantly decreased too, if in 2014 there were 300 buses, in 2013 there were 350 units already that is showed on the figure 1 . 
From 2011 the amount of transported passengers by commercial transport decreased almost from 7,8 till 60 millions people.

In Maykop the most popular urban passenger transport type are commercial buses. Dynamic and structure of transported passengers by different transport types is presented in figures 2 and 3.

There are 36 general transport routes in Maykop, including 25 bus routes, 11 trolleybuses serving 310 commercial small buses and 35 trolleybuses.

The city center is overloaded with transport and pedestrians, especially during peak hours. Low street capacity due to the lack of stop pockets, leads to necessary streets reconstruction, the introduction of additional restrictions and arranging streets with modern traffic organizing technical means.

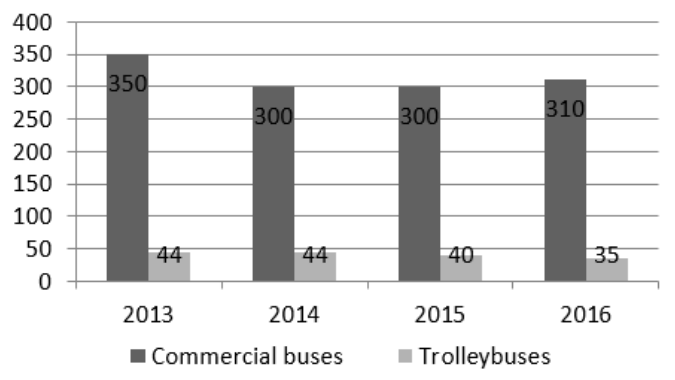

Fig. 1. Dynamic of rolling stock by modes.

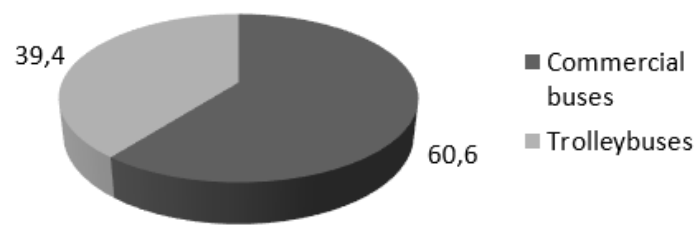

Fig. 2. The structure of transported passengers by transport types in Maykop in 2015.

In 2015 urban transport regulation is $84 \%$, at norm rate, set by KSU CAT is $93 \%$, that shows the insufficient level of passenger service quality [4]. There is a non-official market of private taxi cars transporting passengers in the city. The low taxi passenger transport infrastructure level creates serious difficulties. Taxi cars use for parking public transport stops and grounds that are not equipped in accordance with sanitary and fire safety standards. That cause a number of additional problems in the field of public safety and road safety.



Fig. 3. Dynamic of transported passengers by transport types in Maykop. 
Analyzing this we can highlight several basic factors, that influence both modern state of passenger transport complex in Maykop and the prospects of its development. The positive factors are:

- relatively high level of urban passenger transportation chargeability;

- low level of subsidy dependence in comparison with other cities of the Russian Federation;

- the availability of internal reserves to improve the operational efficiency of Maykop public transport enterprises;

- the passengers transportation average volume with privileges for free travel compared to other cities of the Russian Federation.

Since Maykop has square form, city route network consists of separate parts, each of which has its own routes, that connect in the city center. There are enough transit routes in the city, passing through the center, that difficult working trips in peak hours for people living in districts, adjacent to the city center.

The planning features and geometric parameters of the communication routes have a decisive influence on the characteristics of the traffic flow and the general state of traffic in Maykop. The rectangular scheme of Maykop street-road network is characterized by the presence of parallel highways and the absence of a clearly pronounced center.

Distribution of traffic flows becomes more even. Its disadvantage is the difficulty of transport links between the peripheral city points. To correct this disadvantage, there are planed diagonal lines connecting the most remote points, and the scheme becomes a rectangular-diagonal structure. The coefficient of non-straightness for such a scheme is 1.2$1.3[1,2,3,10]$.

In Maykop the traffic is carried out mainly with traffic light regulation. The movement of passenger transport routes is organized along all the main streets of the city, connecting the central zone with separate areas, as well as villages located outside the city.

The traffic efficiency assumes high-quality road conditions that ensure the minimum possible connection time. The latter depends on the length of the route, the movement speed, and the forced delays at the intersections due to the increase in traffic density. High speed reduces the connection time, but leads to increased fuel consumption and a greater accident risk [3,14-17].

Thus, alongside creation of conditions for high-speed traffic, it is necessary to take measures to limit them.

\section{Results and discussion}

The construction of residential areas in Maykop led to the formation of a new residential infrastructure, which led to people residence place redistribution, the density of population in some parts of the city has changed, and new residential areas have emerged. All this has a significant effect on the transport route network, which does not cope with the growth in traffic volumes, does not meet the quality requirements of transport services for the population. The information about passengers correspondence between the city junctions is required.

At the current city construction pace, it is necessary to revise public passenger transport routes every 3-5 years. The revision of the schemes and the definition of a rational routing network are created taking into account the passenger traffic flow prevailing in the city with the preservation of a larger number of existing passenger transport routes. Consequently, the current scheme changes is no more than $15-20 \%$ of new routes.

Maykop urban transport network analysis shows:

- the end points of urban routes are established, in places of the greatest passengers congestion; 
- the main points of passenger traffic flow in the city and the destination points do not have direct transport links both in the shortest directions with each other and with all city areas, which does not help to reduce trip time;

- urban routes are created on the transport network, as a rule, in the presence of a wellmaintained roadway

- bus transport of general use transport up to $67-70 \%$ of all passenger traffic;

- the network of urban routes basically corresponds to the directions of passenger flows, but does not provide trips without transfers, which reduces the quality of transport services for the population. The lower the interchange rates, the more rationally developed the city route network;

- the condition of the city road network reduces the opportunities for the route network development.

\section{Conclusion}

The direction and length of route network should be formed to provide most transport connections between different city districts: railway and bus stations, industrial enterprises, residential areas etc.

\section{References}

1. V.P. Belokurov, Organization of motor vehicle movement on the street-road network of large cities with regard to unloading their central area / Belokurov V.P., Spodarev

R.A., Pustovalov S.V., Belokurov S.V. // Bulletin of Transport Information. № 3 (261). p. 3-6. (2017)

2. V.P. Belokurov, Management of passenger transportation organization and its peculiarities / Busarin E.N., Artemov A.U., Pustovalov S.V.// Bulletin of Transport Information. № 5 (251). P. 8-12. (2016)

3. U.H. Guketlev, The passenger transport in social and cultural city area and districts // New Technologies. № 4. P. 22-26 (2016)

4. D.A. Dryuchin, The main directions of population transport service quality improvement by city passenger transport on regular routes / Dryuchin D.A., Mayorov M.A. // Vestnik of Orenburg State University. № 4 (179). P. 30-36. (2015)

5. M.V. Kovalenko, Legal regulation of passenger transportation by urban transport // Transport of the Russian Federation. № 5 (24). P. 30-31. (2009)

6. V.A. Korchagin, Regulation of urban transport services market / Korchagin V.A., Grinchenko A.V. // Freight and passenger motor transport. № 7. P. 20. (2008)

7. A.V. Kulev, Improving the efficiency of urban passenger transport functioning/ Kulev A.V., Novikov A.N., Kulev M.V., Kuleva N.S.// Information technologies and innovations in transport, materials of the 2nd International Scientific and Practical Conference. Under the general editorship of A.N. Novikov. P. 378-382. (2016)

8. I.M. Popova, Criteria of quality assessing the urban passenger transport service / Popova I.M., Shustov R.A., Popova E.A. // Scientific and methodical electronic journal Concept. P. 35. P. 126-130. (2015)

9. E.M. Rodkina, Development of an integrated approach to solving public transport services issues / Kozhin G.V., Volodkin P.P. // Actual directions of scientific research of the XXI century: theory and practice.. T. 3. No. 4-1 (15-1). P. 378-383. (2015) 
10. A.S. Tyurin, Functional Modeling of the Process of Transportation Quality Provision of Urban Passenger Mobile Transport / Tyurin A.S., Epifanov V.V.// Mobile Transport Enterprise. № 8. p. 27-30. (2014)

11. S.A. Ulyanova, The Development of Urban Passenger Transport Management System // Vestnik of Transport. № 11. p. 11-12. (2007)

12. U.Kh. Guketlev Management of region transport complex [text]: tutorial // Guketlev U.Kh, Ahunova I.B., Gusaruk Kh.G., Guketlev E.U. - $2^{\text {nd }}$ edition, edt. - Maikop: Publishing house MSTU, - 159 p. (2016)

13. R. Sidorchuk, Marketing evaluation of public transport quality attributes: Review of two waves of research / Sidorchuk, R., Skorobogatykh, I. // Mediterranean Journal of Social Sciences № 6(3S3) C. 275-282 (2015)

14. D. Hidalgo, Implementation of sustainable urban transport in Latin America / Hidalgo, D., Huizenga, C. // Research in Transportation Economics № 40(1), C. 66-77 (2013)

15. C. Willoughby, How much can public private partnership really do for urban transport in developing countries? // Researchin Transportation Economics № 40(1), C. 34-55. (2013)

16. T.A. Kopylova, Level-of-Service concept regarding intermodal hubs of urban public passenger transport // Transportation Research Procedia № 36, C. 303-307. (2018)

17. O. Popova, Principles of modern route systems planning for urban passenger transport // Transportation Research Procedia № 36, C. 603-609. (2018) 